\title{
Internet access and usage by secondary school students in a Nigerian Municipality
}

\author{
Wole Michael Olatokun' \\ Africa Regional Centre for Information Science, University of Ibadan, Nigeria. \\ woleabbeyolatokun@yahoo.co.uk
}

Received: $9^{\text {th }}$ December 2007

Accepted: $10^{\text {th }}$ September 2008

\begin{abstract}
The study investigated the use and patterns of use of the Internet among secondary school students in Ibadan, a Nigerian municipality, with a view to determining how widespread Internet use was and to examine the activities the students adopt the Internet for. It also aimed at determining possible misuse with a view to proffering solutions. A survey research design was adopted. Questionnaire was the instrument for data collection and analysis was done using descriptive statistics. Findings revealed that the majority of the respondents use the Internet for leisure rather than for educational purposes, though some respondents affirmed improved reading habits and academic performances occasioned by Internet use. The greatest barrier to the full exploitation of the Internet was inadequate access. Some inherent risks and problems occasioned by Internet use - namely pornography, scams, etc. - were also identified. The study recommends that there is a need for school authorities and parentsto not only provide Internet facilities for students, but also to adopt strategies to monitor use so as to guard against misuse.
\end{abstract}

Keywords: Access, Internet, secondary school, Ibadan, Nigeria, use, misuse.

\section{Introduction}

The Internet is a global network of computers linked together over large distances. It was created by the American military as a means of communication and has been in existence since the 1950s (Osunade, 2003). Up until the mid- to late eighties mainly commercial organisations and educational institutions used the Internet. This was due to high costs. The rapid development of technology has seen improvement in communication links and a lowering of costs. The implication is that the Internet is now more widely available to more people. The availability and the process by which an effort to use the Internet through an electronic communications system is carried out is referred to as Internet access. The Internet promises to have a far larger and more serious impact on our society than the introduction of television; possibly as great an influence on history as the industrial revolution or the printing press (The UCLA Internet Report, 1999). According to Ojedokun (200I), it has broken down barriers of communication and information access from anywhere in the world. It is fast, reliable and does not have restrictions on content or format. It also has a limitless range of facilities, which assist users to access almost infinite amounts of information. It offers the opportunity for access to upto-date research reports and knowledge globally. It has thus become an important component of electronic services in academic institutions (Ojedokun, 200I).

Globally, the Internet has opened countless new opportunities for students. In fact, it has given a very open approach to education where students are no longer dependent on their teachers or textbooks as their only sources of information. With the Internet in vogue, students are no longer limited to what is in the school library, nor do they have to wait for books to come into the school library. According to the Pew Internet \& American Life Project (2005), Internet use is a staple of college students' educational experience as they use it to communicate with professors and classmates, to do research and to access library materials. For most of them it is a functional tool, one that has greatly changed the way they interact with others and with information as they go about their studies. Thus, the Internet broadens students' horizons beyond their local boundaries (of home and neighbourhood school) and provides an environment in which its impact may be immeasurable.

But in spite of the numerous privileges the Internet has ushered into the students' world, several studies (Li and Chung, 2006; Griffiths, Rogers and Sparrow, 1998; Suhail and Barges, 2006) have established that there are some materials available on the Internet that may be offensive to some students. This might make the Internet be regarded as a strange place just because it is unregulated and unmonitored; its users can be somewhat anarchic and outspoken, to put it mildly. Although it is possible to create network servers that obstruct the avenues to these materials, motivated students quickly identify alternative paths. Thus, despite the numerous benefits of the Internet, there are also many drawbacks. The fact that the Internet is not owned by anyone leaves no room for checks or censorship of available information. The

I. Olatokun, M. Wole,PhD, is a Senior Lecturer at the Africa Regional Centre for Information Science (ARCIS), University of Ibadan, Nigeria 
upside to this is that information is freely available to everyone without restriction, but the downside is that valued information can be placed into the wrong hands, and school children can be unduly exposed to morally damaging information (e.g. pornography). The reason is not far-fetched; it is simply that there are no checks on the information on the net (Osunade, 2003).

Nigeria is a multi-ethnic, multi-cultural, and multi-religious country. There are over 250 different ethnic groups and associated languages (Esiet, et al., 200I). In terms of demographic composition, the country's population is said to be essentially a youthful one (Akinsola, 2005). According to the Nigerian Demographic and Health Survey of 2005 (Federal Ministry of Health, 2005), the total population is made up of $40-45 \%$ children aged $0-15$. Further, $6 \%$ are under 20 years old, about $63 \%$ are under 25 years old, and $30 \%$ are $10-24$ years old. Given the proportion of young people relative to middle-aged and older people in Nigeria, coupled with the reported increased Internet penetration rate in the country (Miniwatts Marketing Group, 2008; Chiemeke \& Longe, 2007), the well-being of the youth cannot but be a matter of concern and object of investigation. The objective of this study was to determine the adequacy of access to, and the usage (in terms of use and misuse) of the Internet by selected secondary school students in Ibadan, a Nigerian municipality. The study also aimed at examining the extent of use, online activities of the students, benefits of Internet use to them as well as identifying the limitations and barriers against Internet exploitation by the students.

\section{Africa Top 10 Internet Countries December 2007}

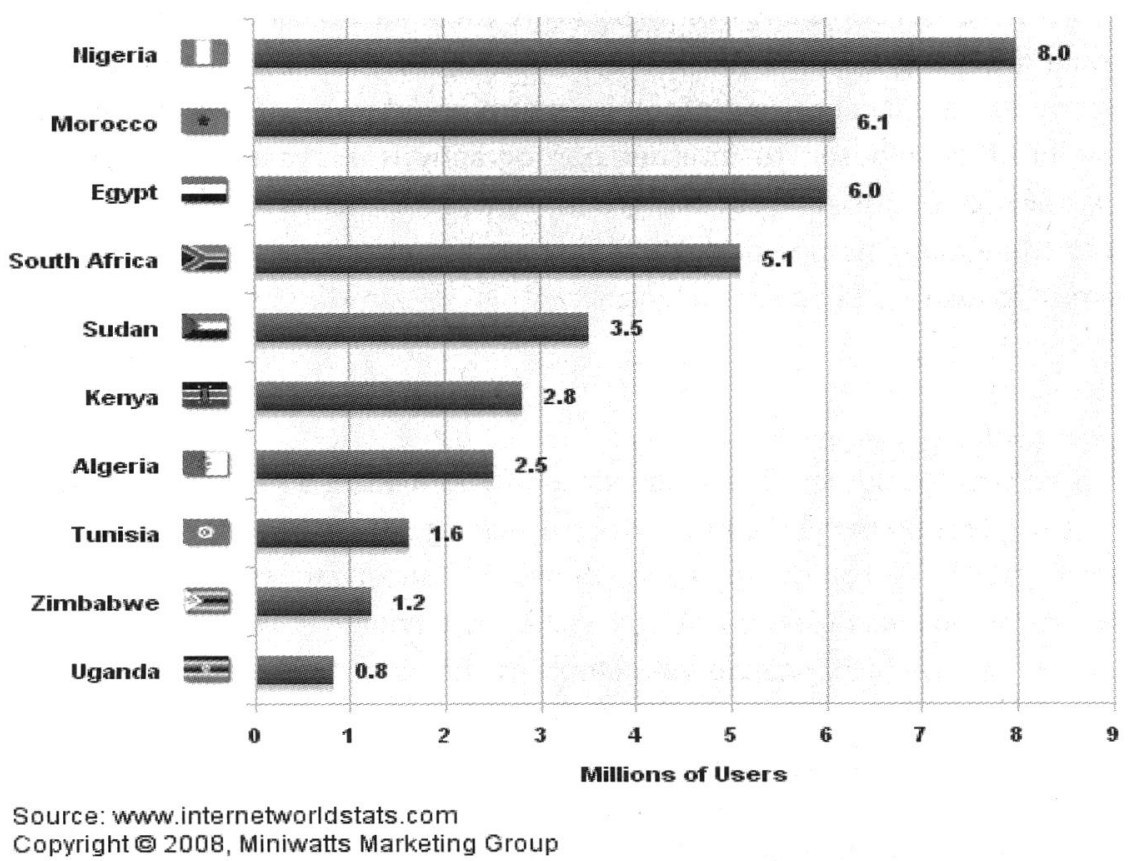

Figure 1 Africa's top 10 Internet countries

\section{Previous studies}

Internet use among secondary school pupils is widespread and growing. According to the Pew Internet \& American Life Project (2005) report, 22.2\% of the 76 million American computer users aged 3 and above use the Internet and one fifth of children with home computers use them to access the Internet. It was also reported that 55 million enrolled children used a computer at school, and the school was the most common place for children to access the Internet. With these staggering numbers, there is little doubt as to the proliferation and popularity of Internet use. A national survey conducted by the Annenberg Public Policy Center (1999) in Washington found that a majority of parents in households with computers fear the Internet's influence on children, due particularly to its wide-open nature and interactivity. However, they still believe that their children need the Internet. They cited as benefits the ability to discover useful things and the advantages for schoolwork. Thus, the Internet is an important element in the overall educational experience of many teenagers. Schools are a common location where online teens access the web, although very few teenagers rely exclusively on their school for that web access. Further, there is widespread agreement among teens and their parents that the Internet can be a useful tool for school (Pew Internet \& American Life Project (2004).

SA Jnl Libs \& Info Sci 2008, 74(2) 
A review of literature reveals that teachers and students are the most frequent users of the Internet, using it mainly for educational purposes rather than for entertainment. Several studies (Jagboro, 2003; Panda and Sahu, 2003; Hanauer 2004) have established a high degree of access and use of the Internet among college students. Hanauer's (2004) report showed that $83 \%$ of Internet users had access at their homes and $51 \%$ at their colleges or libraries. Eighty-one percent of the students access the Internet mostly for college work and $80 \%$ for e-mail/chat. Mishra, Yadav and Bisht (2005) conducted a research study on the Internet usage patterns of undergraduate students at the G B Pant University of Agriculture and Technology, Pantnagar. Their findings indicated that a majority of the students $(85.7 \%)$ used the Internet, and $61.5 \%$ of the males and $51.6 \%$ of the females used it for preparing assignments. A majority of the respondents, $83.1 \%$ male and $61.3 \%$ female, indicated the slow functioning of Internet connections as a major challenge. Robinson (2005) examined Internet use among African-American college students and concluded that the use of the Internet for most of the students occurred at school or in the workplace. In 2002, the Corporation for Public Broadcasting conducted a research on children's Internet use in the United States. Findings revealed that children experienced the equivalent of an adolescent growth in their use of the Internet between 2000 and $2002.65 \%$ of American children ages 2-17 were observed to use the Internet from home, school, or some other location - a 59 percent growth rate since 2000, when 4 I percent of children went online from any location (CTF, 2002).

However, despite the usefulness of the Internet to students, several studies have examined the negative effects it could have on teens. For instance, immoral contents can be viewed in the closet, on a laptop, on a palmtop, etc. without the reservation that any other person will know about the content being consumed. According to Longe, et al. (2007), the Internet has also served as the platform for pedophiles who take undue advantage of the innocence of children and teenagers to engage them in sex chat rooms and eventually invite them for sexual escapades. Hertlein \& Piercy (2006) are of the opinion that people are using the Internet more frequently to form friendships and romances and to initiate inordinate affairs. They provided a critical review of the literature on Internet infidelity. Cheryl (2007) revealed that the average age of a child when first exposed to Internet pornography is II years old, with the largest consumers of pornography in America being the 12-to-17-year old group. Almost 90 percent of eight to 16-year-olds have viewed pornography online, most while doing homework. This study aims at examining the use and mis-use of the Internet by secondary school students in Ibadan - a Nigerian municipality.

\section{Method}

Research design, location and population of the study

The research design adopted was the survey. The study location was Ibadan, a Nigerian municipality. Ibadan was chosen as the location because of proliferation of cybercafés in the city leading to increased access and use of Internet among the youth, which calls for investigation. The study population comprised secondary school students at the junior and senior levels. Purposive sampling technique was used for selecting the respondents in twenty cybercafés The population being indeterminate, the researcher decided to calculate by multiplying the exact figure of the study locations with that of the exact figure of the copies of the research instrument (questionnaire) used for the study. In all, a total of 300 respondents was sampled using randomised sampling.

The data collection instrument used was the questionnaire. It was well structured to clearly identify the important variables to be measured. This included access to the Internet, usage patterns in terms of use and misuse, and the limitations the students encountered in the use of the Internet. It was further designed to elicit some personal information and other views relevant to the study (See Figure I). The questionnaire was examined by experts in Internet research and their comments were used to arrive at the final version. The Cronbach alpha reliability co-efficient of $=0.7 \mathrm{I}$ was achieved

Section A: elicited data about demographic charcteristics of the respondents

Section B: collected data on frequency, extent of use, and places of access to the Internet by the respondents

Section C: asked questions on the Internet facilities used and online activities carried out

Section D: sought respondents opinions about the Internet

Section E: elicited data on the benefits, limitations and inherent risks of Internet use

Figure 2 Structure of the questionnaire

Data were collected in the months of May and June 2007. The researcher visited each of the cybercafés that were chosen as the study location personally to explain the purpose of the study to the management of the cybercafés and to solicit their assistance in administering the questionnaire. In the process, the researcher handed copies of the questionnaire to be administered to them and instructed them on how to briefly interview the respondents before giving out the 
questionnaire so that they could be sure the questionnaire was given to secondary school students. Collected data were structured into grouped frequency distributions using the Statistical Package for the Social Sciences (SPSS) software. Of the 300 copies of the questionnaire administered (fifteen copies per cybercafé), the return rate was 26I, representing $87 \%$. Of the total respondents, $190(72.8 \%)$ were male while $70(26.8 \%)$ were female and I $(0.4 \%)$ did not indicate the gender. The mean age of the respondents was 16 years.

\section{Results and discussion}

In this section, we present the results of data analysis followed by a discussion of the findings.

\subsection{Frequency of Internet use}

Figure 3 shows that 125 (47.9\%) of the respondents use the Internet weekly. A considerable percentage (23.8\%) use it monthly, while only 47 of the respondents use it daily. A small percentage (7.7\%) indicate using it forthnightly, while 7 did not give a response as to their frequency of use of the Internet.

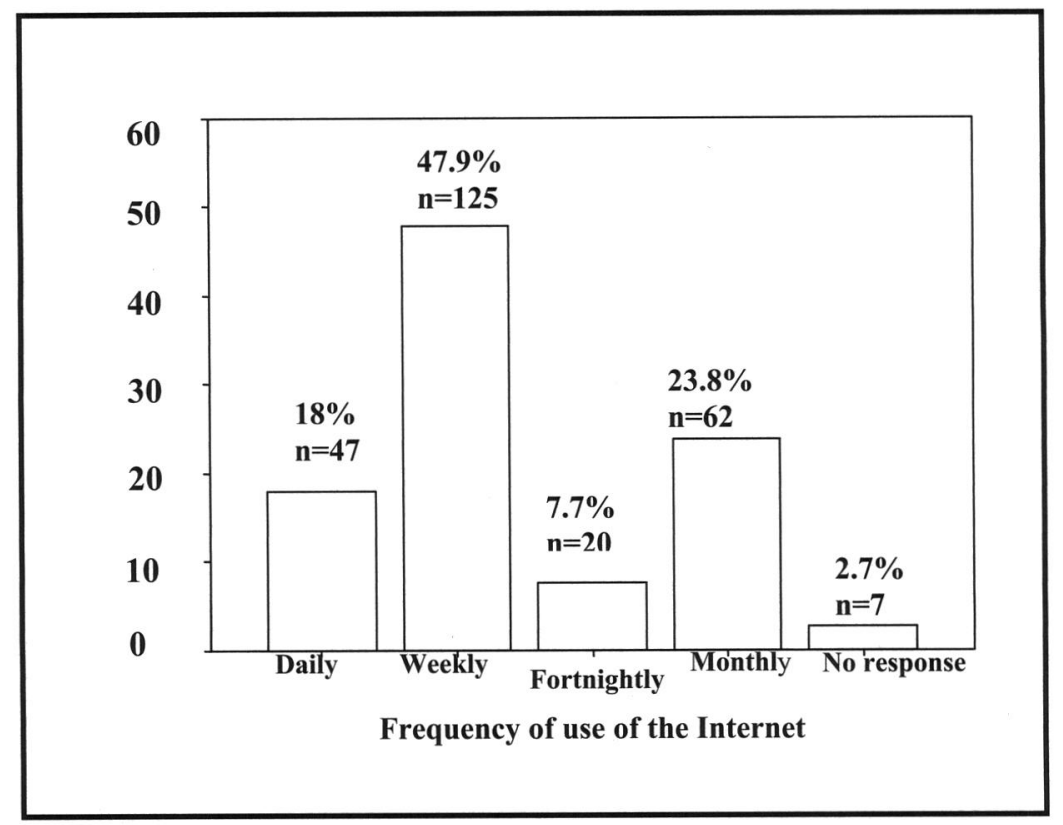

Figure 3 Frequency and use of the Internet

(Source: Field Survey: May 2007)

4.2 Places where students learnt Internet browsing and average time spent daily

Table I: Frequency distribution of the place where students learnt to browse the Internet

\begin{tabular}{llcccc}
\hline & Frequency & Percent & Valid Percent & $\begin{array}{c}\text { Cumulative } \\
\text { Percent }\end{array}$ \\
\hline Valid & At home & 48 & 18.4 & 18.4 & 18.4 \\
& At school & 16 & 6.1 & 6.1 & 24.5 \\
& At a cybercafé & 184 & 70.5 & 70.5 & 95.0 \\
& Others & 13 & 5.0 & 5.0 & 100 \\
& Total & 261 & 100 & 100 & \\
\hline
\end{tabular}

Source: Field Survey: May 2007

It was of interest to find out how students who used the Internet came to learn its use. The majority 184 (70.5\%) indicated that they learnt how to browse the Internet in the cybercafés showing the importance of the cybercafé in increasing access to Internet facilities. Forty-eight (18.4\%) of them learnt it at home while $16(6.1 \%)$ of them learnt it in school). Thirteen (5.0\%) indicated that they learnt to use it in other places, e.g. their father's, an uncle's or aunt's office. 
4.3 Average time spent on the Internet by the students

Table 2 Frequency distribution of average time spent on the Internet

\begin{tabular}{lccccc}
\hline & Frequency & Percent & Valid Percent & $\begin{array}{c}\text { Cumulative } \\
\text { percent }\end{array}$ \\
\hline Valid & Less than 30 min & 17 & 6.5 & 6.5 & 6.5 \\
& 30 min - I hour & 97 & 37.2 & 37.2 & 43.7 \\
I - 2 hours & 111 & 42.5 & 42.5 & 86.2 \\
More than 2 hours & 30 & 11.5 & 11.5 & 97.7 \\
No response & 6 & 2.3 & 2.3 & 100.0 \\
Total & 261 & 100.0 & 100.0 & \\
\hline
\end{tabular}

Source: Field Survey: May 2007

On daily usage of the Internet, III (42.5\%) spend an average of I-2 hours, a considerable number 97 (37.2\%) spend between 30 minutes and I hour and 30 (II.5\%) spend more than 2 hours on the Internet daily. Six $(2.3 \%)$ respondents gave no response.

4.4 Internet facilities used by the respondents

The study sought to know the facilities frequently used on the Internet. The results are presented in Table 3.

Table 3 Percentage of use of Internet facilities

\begin{tabular}{lll}
\hline \multicolumn{1}{c}{ Internet Facilities } & \multicolumn{1}{c}{ Frequently used } & Not used at all \\
\hline E-mail & $92.3 \%(24 \mathrm{I})$ & $7.6 \%(20)$ \\
Internet Relay Chat Room & $69.4 \%(18 \mathrm{I})$ & $30.6 \%(80)$ \\
World Wide Web & $55.5 \%(145)$ & $44.5 \%(116)$ \\
Instant Messaging (IM) & $48.3 \%(126)$ & $51.7 \%(135)$ \\
News and travel information & $37.6 \%(98)$ & $62.5 \%(163)$ \\
Discussion groups \&Newsgroups & $32.5 \%(85)$ & $67.5 \%(176)$ \\
Electronic commerce facilities & $29.1 \%(76)$ & $70.9 \%(185)$ \\
Wide Area Information Server (WAIS) & $27.5 \%(72)$ & $72.4 \%(94)$ \\
Archie & $25.3 \%(66)$ & $74.7 \%(195)$ \\
File transfer protocol & $23 \%(60)$ & $77.0 \%(201)$ \\
Telnet connections & $22.2 \%(58)$ & $77.8 \%(203)$ \\
Gopher & $16.8 \%(44)$ & $83.2 \%(121)$ \\
\hline
\end{tabular}

Source: Field Survey, May 2007

Table 3 shows that $92.3 \%(24 I)$ of the respondents indicated that they make use of the electronic mail frequently. Only $7.6 \%$ (20) of them affirmed that they had never used the e-mail. Internet Relay Chat Room was the next facility frequently used with $181(69.4 \%)$ respondents while $30.6 \%(80)$ of them said they had never used the facility. The WWW was next in the hierarchy with $145(55.5 \%)$ indicating that they used it and $116(44.5 \%)$ indicating that they do not use it. The least significant facilities used by the majority of the respondents were Gopher 121 (83.2\%), Telnet 203 (77.8\%), File Transfer Protocol 201 (77.0\%), Archiel 95 (74.7\%) and Wide Area Information Server (WAIS) 94 (72.4\%) in that order.

4.5 Activities carried out by the students online

The study sought to find out the activities the students use the Internet for when online. The findings are presented in Table 4. 
Table 4 Online activities carried out by the students

\begin{tabular}{|c|c|c|}
\hline Online Activities & Significantly done & Not done at all \\
\hline Reading \& Sending e- mail & $84.3 \% \quad(220)$ & $\mid 5.7 \%(4 \mid)$ \\
\hline Online chatting with old \& new friends & $77 \%$ & $23 \% \quad(60)$ \\
\hline Playing \& downloading music & $62.5 \% \quad(163)$ & $37.6 \% \quad(98)$ \\
\hline Browsing for fun & $57.5 \% \quad(150)$ & $42.6 \%(111)$ \\
\hline Playing \& downloading games & $45.9 \% \quad(120)$ & $54 \%(14 I)$ \\
\hline Homework & $46.4 \% \quad(121)$ & $53.6 \%(140)$ \\
\hline Instant Messaging (IM) & $52.4 \% \quad(137)$ & $47.5 \%(124)$ \\
\hline Visiting websites & $55.4 \% \quad(194)$ & $25.6 \%(67)$ \\
\hline Reading newspapers & $(120)$ & $54 \%(141)$ \\
\hline Searching for information & $70.9 \% \quad(185)$ & $29.1 \%(76)$ \\
\hline
\end{tabular}

Source: Field Survey, May 2007

The results in Table 4 showed the following distribution: reading \& sending e-mail (84.3\%); online chatting with old \& new friends (77\%); searching for information (70.9\%); playing \& downloading music (62.5\%); browsing for fun (57.5\%); visiting websites (55.4\%) and Instant Messaging (IM) (52.4\%). Few of them indicated they use the Internet for homework (46.4\%); reading newspapers (46\%), playing and downloading games (45.9\%). These findings showed that the majority of the respondents were not using the Internet for academic matters as one would have expected since "reading \& sending e-mails" and "online chatting with old and new friends" ranked highest and the use for "homework" is one of the lowest.

4.6 Factors responsible for widespread Internet usage among the students

For further investigation on the use of the Internet by the respondents, they were asked to indicate the factors that are responsible for widespread Internet usage among them. A large percentage of $83.5 \%$ of the respondents believed that ease of use is part of the factors responsible for widespead Internet usage. This was followed by $78.2 \%$ who believed the major factor was because "it is in vogue". About sixty-eight per cent indicated that the reason for the widespread use was "to source for information" The least reason that accounted for Internet use, according to the respondents was "parents encouragement".

4.7 Respondents' perception and opinions about the Internet

Table 5 Respondents' opinions about the Internet

\begin{tabular}{|c|c|c|c|}
\hline Opinions & Total Disagree & Total Agree & No Response \\
\hline It is a waste of time & $63.7 \%(166)$ & $17.2 \%(45)$ & $19.1 \%(50)$ \\
\hline It helps to improve my academic performances & $37.9 \%(99)$ & $45.2 \%(118)$ & $16.8 \%(44)$ \\
\hline It keeps users away from families and friends & $60.5 \%(158)$ & $18 \%(47)$ & $21.5 \%(56)$ \\
\hline The quality of information on it is poor & $73.2 \%(191)$ & $5.7 \%(15)$ & $21.1 \%(55)$ \\
\hline It is difficult to browse the Internet & $65.9 \%(172)$ & $11.1 \%(29)$ & $22.9 \% 60)$ \\
\hline It is a resource for general knowledge & $20.6 \%(54)$ & $60.9 \%(159)$ & $18.4 \%(48)$ \\
\hline It exposes children to offensive materials e.g. pornography & $23.8 \%(62)$ & $52.5 \%(137)$ & $23.8 \%(62)$ \\
\hline It will be good if my school is connected to the Internet. & $10.5 \%(27)$ & $68.6 \%(179)$ & $21.1 \%(55)$ \\
\hline Internet is used among all secondary school students & $34.5 \%(90)$ & $33.3 \%(87)$ & $32.2 \%(84)$ \\
\hline The Internet is addictive & $20.7 \%(54)$ & $41.7 \% \quad(109)$ & $37.6 \%(98)$ \\
\hline \multicolumn{3}{|c|}{ My school library is still far better and more convenient to get information } & $28.4 \%(74)$ \\
\hline The Internet has some inherent risks & $32.2 \%(84)$ & $31.5 \%(82)$ & $33.4 \%(95)$ \\
\hline
\end{tabular}

Source: Field Survey: May 2007

Table 5 presents the varied view and perception of the Internet by the respondents. More than half of the respondents (172) reported that they have no difficulty in browsing the Internet because it is user friendly. $166(63.7 \%)$ indicated that 
they do not see the Internet as a time waster because they enjoy the great exposure it has brought to them. Majority of them said though their schools are not connected to the Internet, yet they see it as far better and convenient to use than their school libraries. Therefore they considered every time they browse the Internet an opportunity to add to their knowledge, which invariably over time has helped to improve their academic performances.

\subsection{Benefits of Internet use}

Table 6 Frequency distribution of the benefits derived from Internet use

\begin{tabular}{llll}
\hline \multicolumn{1}{c}{ Benefits } & \multicolumn{1}{c}{ Yes } & \multicolumn{1}{c}{ No } & No Response \\
\hline Keeping in touch & $82.8 \%(216)$ & $16.5 \%(43)$ & $0.7 \%(2)$ \\
Getting current information & $82.4 \%(215)$ & $17.6 \%(46)$ & $0 \%(0)$ \\
Information for homework & $60.2 \%(157)$ & $39.1 \%(102)$ & $0.7 \%(2)$ \\
Exposure to global issues & $75.5 \%(197)$ & $24.5 \%(64)$ & $0 \%(0)$ \\
Improved Reading Habits & $55.6 \%(145)$ & $44.1 \%(I 15)$ & $0.3 \%(1)$ \\
Making friends & & $28.0 \%(73)$ & $0 \%(0)$ \\
\hline
\end{tabular}

Source: Field Survey: May 2007

Table 6 shows that a large percentage (82.8\%) indicates that "keeping in touch" is one of the benefits derived from the use of the Internet, $82.4 \%$ believed it is good for "getting current information" while $75.5 \%$ indicated that "exposure to global issues" is one of the benefits of the use of the Internet. A considerable proportion (55.6\%) indicated "improved reading habits", "getting information for homework" $(60.2 \%)$ as the benefits derived.

4.9 Limitations to Internet usage

Table 7 presents the findings on the limitations of Internet use.

Table 7 Extent of limitation to Internet usage

\begin{tabular}{llll}
\hline \multicolumn{1}{c}{ Limitations } & \multicolumn{1}{c}{ High Extent } & Low Extent & No Response \\
\hline Too expensive & $23.7 \%(63)$ & $52.8 \%(138))$ & $26.0 \%(60)$ \\
Inaccessibility & $24.2 \%(58)$ & $52.8 \%(135)$ & $22.9 \%(68)$ \\
No guidance/training on how to use the Internet & $19.2 \%(50)$ & $54.4 \%(142)$ & $26.4 \%(69)$ \\
Discouragement from parents & $13.0 \%(34)$ & $52.1 \%(136)$ & $34.8 \%(9 I)$ \\
Lack of adequate time to use the Internet & $27.6 \%(72)$ & $46.4 \%(121)$ & $36.0 \%(68)$ \\
Inherent health risks/hazards & $18.0 \%(47)$ & $52.9 \%(138)$ & $29.2 \%(76)$ \\
Inability to get required information & $20.3 \%(53)$ & $48.6 \%(127)$ & $31.0 \%(8 I)$ \\
Boredom & $12.2 \%(3 I)$ & $57.5 \%(150)$ & $20.6 \%(80)$ \\
\hline
\end{tabular}

Source: Field Survey: May 2007

Findings presented in Table 7 showed that lack of adequate time to use the facility, inaccessibility, high cost and inability to get the required information have very great extent in limiting the respondents' Internet usage. The results also revealed that a large proportion of them (57.5\%) believed that boredom limits their Internet usage but at a low extent. In addition, factors such as "no guidiance/training on how to use the Internet", "discouragement from parents" and "inherent health risks/ hazards" were indicated as limiting factors but to a low extent.

\subsection{Discussion of findings}

In the past five years, the use of the Internet has become widespread in Nigeria. This is confirmed from a study report by Internet World Stats (2008) which says that as at the year 2000, the total number of Internet users in Nigeria was just 200,000 but at present the number has drastically increased to 10 million. The fact still remains that young people are always excited and full of enthusiasm to explore whatever is new in the society, therefore it will not be an understatement to say that they constitute a larger proportion of Internet users in Nigeria. The findings revealed that a large proportion of the secondary school students in Nigeria had been involved to some extent in using the Internet in their everyday lives for about four to five years now. They use the Internet for between I-2 hours daily. This is in line with reported findings from 
the Pew Internet \& American Life Project (2005) that many American teenagers are heavy, enthusiastic users of the Internet with about $62 \%$ of them going online every day. It equally corroborates the Environics Research Groups for the Media Awareness Network (2005) report that Canadian youths are no strangers to the Internet. Almost 8 in 10 (79\%) of them say they have Internet access at home, (48\%) say they use the Internet from home at least an hour every day.

However, findings from this study revealed the cybercafé as the one major place of access to Internet facilities which contrasts with the Pew Internet \& American Life Project survey report (2004) which found that $87 \%$ (2I million) of all American youth between the ages of 12 and 17 use the Internet. Of these 21 million online teens, $78 \%$ (or about 16 million students) say they use the Internet at school, meaning that $68 \%$ of all teenagers have used the Internet at school. This contrast is largely due to the fact that most of the secondary schools in Nigeria (those in the study area inclusive) are ill-equipped with Internet facilities if at they have them.

Findings also revealed that male respondents constitute $72.8 \%$ of total population of Internet users, while female constitute $26.8 \%$. This result could be linked to established facts in the literature that technology is a male sphere, and research has also shown that boys have greater interest in technology than the females (Enochsson, 2005). This result also reflected the outcome of earlier statistics where the male use the Internet more than the female gender (Noguchi, 2005). But it is contrary to more recent statistics which shows that girls and women are as frequent Internet users as men (Fallows, 2007 and Enochsson, 2005). This finding equally corroborates the notion that majority of Internet users in cybercafés in developing countries are males and are students (Jagboro, 2003; Wahid, Furuholt and Kristainsen, 2006; and Sairosse, 2003).

Another salient finding in the study is that which relates to the main purposes why students use the Internet. One would have expected that surfing, retrieving and using information especially for educational purposes would rank very high in the respondents' use of the Internet but this turned out to be the contrary as their primary use of the Internet was for communication, entertainment, and leisure (e.g., reading and sending e-mail, online chatting, instant messaging, playing and downloading music and games and reading newspapers) (Hoag, 2003; Jones \& Madden, 2002, Pew Internet \& American Life Project, 2005, Environics Research Groups for the Media Awareness Network, 2005), and only secondarily used for homework. The social interactions allowed by the Internet, particularly the synchronic (e.g., chat) rather than the asynchronic communication forms (e.g., fora), seem to meet significant needs of the respondents. This is in line with the findings of the Pew Internet \& American Life Project, (2005). The finding of course has come as no surprise, since it mirrors experiences of Internet usage in countries like America, Canada, Australia (Fleming and Rickwood, 2004; Environics Research Groups for the Media Awareness Network (2005); Pew Internet \& American Life Project, 2005).

Moreover, this study reveals that Internet usage among students is widespread, given that it is commonly available in the diversely established cybercafés that are set up mostly as one-man businesses in every nook and cranny of Nigeria. Also, majority of them perceived that using the Internet is a modern thing to do, and that at present, on a global view, it is in vogue. For these students, the cost of using the Internet is not expensive and besides they see the Internet as a source of all information that allows them to check global trends of events and news stories. Furthermore, the respondents affirmed that they receive a lot of encouragement from their schoolteachers to use the Internet. This could be said to be in line with the interview granted to some teachers by Gibson and Oberg's (1997) case study of Internet use which reported that the predominant student uses of the Internet in schools were exploring Web sites and visiting sites identified by their teachers. Besides that, majority of the students established that their parents encourage them to use the Internet. This contrasts the findings of the Pew Internet \& American Life Project (2005) that reported parents having many concerns about the Internet and struggle to protect their children from the worst elements online - dreadful people and ugly information - without keeping children from its benefits. For instance, parents of girls are more concerned than parents of boys that their children will be victimized online - that they will be stalked, harassed, and that they will be susceptible to advertising. This clearly carries over to the Internet the concerns that girls' parents have about all kinds of experiences and threats. Wired parents were generally much less worried about the impact of the Internet on their children than parents who did not have Internet access. Online parents tend to be more vigilant in monitoring what their children do on the Internet, but also seem more confident that they could avoid trouble. Parents with considerable online experience express even less concern than those who have recently come online. For their part, online teens as a group were generally much less concerned than parents about online content and do not feel as strongly that they need to be protected (Pew Internet \& American Life Project 2005).

On the benefits of Internet usage, the respondents reported that they appreciate the speed of the Internet, the variety of information it contains in one spot, and the ease of access to it, and they believe that information on the Web is more up-to-date than those in books (Fidel et al., 1999; Parr, 1998). High school students told researchers that they thought it was easier and more interesting to find information on the Web than in the library, and that they did not plan their Internet searches (Fidel et al., 1999). This is in agreement with responses from a large proportion of the respondents.

SA JnI Libs \& Info Sci 2008, 74(2) 
Most of them believe the Internet is far better and convenient than their school libraries, they saw it as a source for general knowledge; hence they established that it has really helped them to improve their reading habits and their academic performances. They saw it as a technology that has brought them opportunity to access countless documents and send information to all parts of the globe. In addition, a large proportion indicated that the Internet has brought quite a lot of benefits to them such as making new friends, getting current information, exposure to the global view of any topical issue. Some see the Internet as a means of keeping in touch with friends and relatives. Despite the motivational factors identified as the cause of widespread use of the Internet among the secondary school students, factors such as uneasy access, lack of good guidance, time consumption, inability to get the required information, attached health risk and boredom has been identified to be responsible for the limited use of the Internet, though at a low extent. Other problems acknowledged by the students were the inherent risks, offensive materials (e.g. pornography, scam, etc) and its addictive influence. This is consistent with Griffiths (2003), Mitchel et al (2005), Li and Chung (2006), Suhail and Barges (2006), and Environics Research Groups for the Media Awareness Network (2005). Similarly, as reported in the findings of the Pew Internet \& American Life Project (2005), the addictive influence and exposure to offensive materials form major concerns of American parents, especially those with considerable online experience. They were concerned with what their children might see or read online and about half (45\%) of parents are worried that the Internet leads some young people to do dangerous or harmful things. Such parents have devised means of controlling their children's access such as carrying out on-the-spot checks, surfing together with their children, fixing computers in the open place where they could keep an eye on their children's online activities, or using filters (Pew Internet \& American Life Project 2005).

\section{Conclusions and recommendations}

The Internet could be likened to a giant growing archive accessible to all literate being of any age range. The use of the Internet grants its users great awareness of the importance of the world around them and it will continue to grow as long as its users are not denied of easy access. Knowledge is power and knowledgeable youths are the leaders and builders of better and greater tomorrow. The Internet stands to be a source of knowledge and any country that severe her youth from it by failing to provide adequate facilities for easy access is unseating the country from her throne of dignity among other dignitaries. Governments of countries such as the United States of America, Canada, United Kingdom, and Australia have realised this and hence have incorporated Internet connectivity at all levels of education in their countries. This study established the popularity of the Internet among secondary school students and that it is a source of all information for them and is far better, more convenient and reachable than their school libraries. However, some of the students are yet to have enhanced access to the Internet in their schools. In this connection, the following recommendations are made:

First, the Nigerian government should better fund the public secondary schools with a view to providing quality education at this level. Better funding will also lead to better facilities in the schools including the Internet. This will no doubt increase access and use of the Internet in the schools and will assist them in their academic endevours. Second, judging from the findings of this study, the cybercafé turned out to be a major point of access to Internet facilities by the students. In line with this, it is recommended that the government should embark on the creation of telecentres in the nook and cranny of the country, particularly in the major cities. This will further increase access and use of the Internet among the students. Also, where it is found that students merely want to use Internet facilities for communication and entertainment purposes only, teachers in the respective schools should promote meaningful Internet use by referring them to search for information on subject topics and present written details of what they have learnt. In other words, schoolteachers should refer students to websites for additional information that will help to improve them academically. The additional information will complement the classroom teaching and widen the student's concept of the topic they have learnt. They should also encourage the students to visit specific websites in advance preparation for topics that will be taught later in class. Finally, cybercafés should be encouraged to partition their services to adult, youth and children/ teen sections in order to take advantage of technologies for content channeling/selection (Longe, et al 2007). While some computer terminals can be dedicated to access all forms of contents others for children/teenagers usage can be enabled to access contents that are purely healthy for children/teenagers' age group consumption. The responsibility of monitoring Internet contents being consumed by children and youths at home rests with parents and guardians. Content channeling/selection technologies and filters could be used as an aid to moderating contents viewed by children/teenagers at all Internet access points. In schools, students can be allocated user and password IDs. These passwords and IDs can then be configured and made usable only on systems that have been conditioned using filters and content selection technology for web contents that are healthy for the consumption of children and teenagers (Longe, et al, 2007).

SA Jnl Libs \& Info Sci 2008, 74(2) 


\section{References}

Affonso, B. (1999). Is the Internet affecting our children? (Internet) http://www.wes.org/ewenr/04Sept/Practical.htm. January 22, 2007.

Akinsola, E.F. (2005). Comments on empowering youths through sexuality education: the challenges and opportunities. Retrieved on $13^{\text {th }}$ September 2006, from: www.arsrc.org/downloads/akinsola.pdf.

Cheryl, T. (2007). Keep Your Child Safe from Internet Porn. Retrieved February 13, 2007 from online at www.cbn .com

Chiemeke, C. S, \& Longe, O. B. (2007). Information and Communication Penetration in Nigeria: Prospects, Challenges and Metrics. Asian Journal of Information Technology, 6(3), 280-287.

CTF (2002). Connected to The Future A Report on Children's Internet Use. Retrieved from The Corporation for Public Broadcasting Retrieved on 16 May 2008 from: cpb.org/ed/resources/connected

Enochsson, A. (2005). Gender Perspective on Internet Use: Consequences for Information Seeking, (Internet). Retrieved on $2^{\text {nd }}$ July 2007 from $h t t p: / /$ informationr.net/ir/index.html

Environics Research Groups for the Media Awareness Network (2005). "Young Canadians in a Wired world: Key Findings" Retrieved on $24^{\text {th }}$ September 2007 from: http://www.media-awareness.ca/english/resources/special_initiatives/survey_resources/ students_survey/key_findings/kids_online_key_findings. cfm.

Esiet, U.E., Bello, M.V., Adebayo, C.O., Booth, R., (200I). Sexuality in Nigeria, in the International Encyclopaedia of Sexuality, Retrieved on $17^{\text {th }}$ May, 2008 from: http.www. 2.hu-berlin.de/sexology.IES/Nigeria.

Fallows, D. (2005). How Women and men use the Internet. Pew Internet and American life project, Retrieved on $10^{\text {th }}$ January 2007 from: http://www.pewinternet.org

Federal Ministry of Health. (2005). Nigeria demographic and health survey reports. Nigeria: Federal Ministry of Health.

Fidel, R. D., Rachel, K., Douglass, M. H., Holder, J. K., Hopkins, C. J., Kushner, E. J., (1999). A visit to the information mall: Web searching behavior of high school students. Journal of the American Society for Information Science, 50(I), 24-37.

Fleming, M. and Rickwood, D. (2004):'Teens in cyberspace: Do they encounter friend or foe?' Youth Studies Australia, vol.23, no.3, pp.46-52. Retrieved on 05 ${ }^{\text {th }}$ March 2007 from: http://www.youthfacts.com.au /index. php?option $=$ displaypage\&ltemid= 262\&op= page.

Gibson, S., \& Oberg, D. (1997). Case studies of Internet use in Alberta schools: Emerging issues. Canadian Journal of Educational Communication, 26, pp.145-164.

Griffiths M. (2003): Internet abuse in the workplace: issues and concerns for employers and employment counsellors. Journal of employment Counselling 40. 87-96

Griffiths M.D, Rogers M.E., and Sparrow, P. (1998) Crime and IT (Part II): Stalking the Net. Probation Journal 45: 138-I4I

Hanauer, D. (2004). Internet Use among Community College Students: Implications in Designing Healthcare Interventions. Journal of American College Health, 52 (5), pp 197-202.

Hertlein, K. M. \& Piercy, F. P. (2006) "Internet Infidelity: A Critical Review of the Literature" The Family Journal, Vol. I4, No. 4, 366-37I.

Hoag, J. C. (2003). Residential Perceptions of Internet Service Quality: Result of a Survey Retrieved on $30^{\text {th }}$ August 200 from: $h t t p: /$ /www.nrri.ohio-state.edu/dspace/bitstream/2068/205/l/03-0I.pdf

Jagboro, K.O (2003). A study of internet usage in Nigerian Universities: A case study of Obafemi Awolowo University, lle-Ife, Nigeria. Retrieved 6th August 2008 from: http://www. First:Monday.dk/issues8-2/Jagboro

Jones S and Madden M. (2002): The internet goes to college: how students are living in the future with today's technology. Washington, D.C: Pew internet \& American life project. Retrieved I I th September 2006 from: www.pewinternet.org/reports/ $\mathrm{pd} / \mathrm{s} / \mathrm{pip}$-college-report.pdf.

Li; S and Chung; T. (2006): Internet function and internet addictive behaviour. Computer in Human Behaviour 22(6) 1067-107I.

Longe, O. B.; Chiemeke, S. C.; Onifade, O. F. W.; Balogun, F. M.; Longe, F. A. \& Otti, V. U. (2007) "Exposure of Children and Teenagers to Internet Pornography in South Western Nigeria: Concerns, Trends \& Implications" Journal of Information Technology Impact Vol. 7, No. 3, pp. 195-2I2.

Miniwatts Marketing Group (2008) Africa Top 10 Internet Countries. Retrieved on 12 May 2008 from: http:// www.internetworldstats.com/stats I.htm

Mishra, O.P., Neelam, Y. \& Kamini, B.(2005). Internet Utilization Pattern of Undergraduate Students. University News 43, 13 , pp8-12.

Mitchel K.J, Finkelhor D and Wolak J (2005): The internet and family and acquaintance sexual abuse. Child Maltreatment I0(I) 49-60. Retrieved $16^{\text {th }}$ February 2006 from http://www.innovatioinlaw.org/pages/child-docs/cv93.pdf.

Noguchi, Y. (2005). Women Narrow the Internet Gender Gap, survey finds. Washington Post. Thursday, Dec. 29. Retrieved on 13 April 2008 from: $h t t p: / / w w w . w a s h i n g t o n p o s t . c o m / ? n a v=p f$

Ojedokun, A. A. (200I). Internet Access and Usage by Students of the University of Botswana. African Journal of Library, Archives and Information Science, Vol. II, No.2, 97-107.

Osunade, O. (2003). An evaluation of the impact of Internet browsing on students' academic performance at the tertiary level of education in Nigeria. Retrieved on $15^{\text {th }}$ March 2007 from: http://www.rocare.org/smallgrant_nigeria2003.pdf.

Panda, K. C., and Sahu, N. K. (2003). Use of Internet in the Engineering Colleges of Orissa: An Analysis. Conference, Mapping Technology on Libraries and People. Ahemdabad, India: Proceedings of the Ist International Conference on Mapping Technology on Libraries and People. pp 619-631.

Pew Internet \& American Life Project (2004) The Internet Goes to College: How students are living in the future with today's

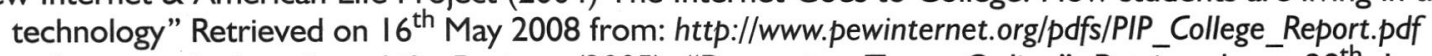

Pew Internet \& American Life Project (2005) "Protecting Teens Online" Retrieved on $28^{\text {th }}$ June 2008 from: http:// www.pewinternet.org/pdfs/PIP_Filters_Report.pdf.

Robinson, J. W. (2005). Internet Use among African-American College Students: An Exploratory Study. Retrieved 9

February, 2007, from http://wwwlib.umi.com/dissertations/fullcit/31560/5.

SA Jnl Libs \& Info Sci 2008, 74(2) 
Sairosse, M.T. (2003): Economic and social impact of the internet: study of cybercafés in Gaborone, Botswana. MLIS. Dissertation, dept. of Library and Information studies, University of Botswana.

Suhaul K. and Barges, Z. (2006): Effects of excessive internet use in undergraduate students in Pakistan. Cyber psychology and Behaviour. 9(3) 297-307.

The UCLA Internet Report (1999) Surveying the digital future: How the PC and Internet are changing the world. Los Angeles, CA: UCLA Center for Communication Policy. Retrieved on $5^{\text {th }}$ March, 2007 from: $h t t p: / / c c p . u c l a . e d u / o n e ~ p a g e . h t m$.

U.S. Census Bureau. (1997). Computer use in the United States. Washington, DC. Retrieved on $26^{\text {th }}$ May 2007 from: http:// www.census.gov/prod/99pubs/p20-522.pdf.

Wahid, F; Furuholt, B. and Kristiansen, S. (2006): “Internet for development? Patterns of use among internet cafe customers in Indonesia" Information Development 22(4) 278. Retrieved 18 December, 2006 from: http://idv.sagepub.com/cgi/content/ abstract/22/4/278.

\section{Appendix}

Biodata of the author

\section{Olatokun, Wole Michael}

Dr. Wole Michael Olatokun obtained his Master and PhD degrees in Information Science from the University of Ibadan . $\mathrm{He}$ is currently a Senior Lecturer at the Africa Regional Centre for Information Science (ARCIS), University of Ibadan, Nigeria. He can be contacted by e-mail at:woleabbeyolatokun@yahoo.co.uk. 